\title{
EXPORT SPECIALISATION AND OUTPUT SYNCHRONISATION IN THE EURO AREA: THE CASE OF SOUTHERN COUNTRIES*
}

\author{
Sofia Helena GOUVEIA \\ (Received: 1 December 2014, revision received: 18 September 2015; \\ accepted: 2 December 2015)
}

\begin{abstract}
Business cycle synchronisation and the similarity in the sectoral structure of exports are key conditions for the successful implementation of common monetary policy, as shown by the theory of Optimum Currency Areas. This paper examines the degree of correlation between the aggregate euro area and 12 member states' business cycles and the role of their exports specialisation dynamics vis-à-vis the euro area over the period 1981-2012, focusing in particular on Southern European countries. Overall, we find that since the inception of the European Monetary Union, the business cycles of euro area member states have been increasingly synchronised with the aggregate euro area cycle, with the exception of Greece. We also document that changes in the Greek, Portuguese, and Spanish export structures brought these countries closer to the euro area structure as a whole. Furthermore, we find a positive and significant relationship between the similarity of export structures and GDP cyclical correlations.
\end{abstract}

Keywords: specialisation, business cycles synchronisation, optimum currency area, Southern Europe

JEL classification indices: E32, F15, F41

* I am grateful to the two anonymous referees and to participants at the $13^{\text {th }}$ EACES Conference (Budapest, September 4-6, 2014) for their useful comments. The usual disclaimer applies.

Sofia Helena Gouveia, Department of Economics, Sociology and Management (DESG), Centre for Transdisciplinary Development Studies (CETRAD), University of Trás-os-Montes and Alto Douro (UTAD), Quinta de Prados, Vila Real, Portugal. E-mail: sgouveia@utad.pt 


\section{INTRODUCTION}

The international financial crisis of 2008-2009 and the subsequent euro area sovereign debt crisis have renewed interest in the question of the sustainability of the European Monetary Union (EMU). The creation of the euro was supposed to contribute towards a gradual real economic convergence (e.g. Buti - Sapir 1998). Nevertheless, a number of recent studies (Chen et al. 2013; Gunther Wollmershäuser 2013; Kim - Kim 2014) have documented that the introduction of the euro has promoted growing macroeconomic imbalances among EU member states.

The Optimum Currency Areas (OCA) theory (Mundell 1961; Mckinnon 1963; Kenen 1969) argues that the net benefits of a currency union depend on the degree to which its member states fulfil the OCA criteria. Among these criteria, the degree of business cycle synchronisation plays a crucial role because a common monetary policy will be easier to implement if the member countries' business cycles are aligned.

According to the Kenen (1969) criterion, the similarity in the sectoral structure of exports across the members of a currency union may reduce the incidence of idiosyncratic shocks. If shocks are more symmetric across countries, real variables tend to respond more similarly. In particular, the process of the homogenisation of sectoral structures of exports is an important feature in real convergence as well as being a potential determinant of the degree of the similarity of cycles.

In turn, Frankel - Rose (1998) have highlighted the positive impact that increasing trade integration has on the degree of output fluctuation, invoking the argument of the "endogeneity of OCA's criteria." In other words, the criteria are satisfied ex-post even if they are not met ex-ante. ${ }^{1}$ According to this hypothesis, a single monetary policy would be a "one size fits all" policy. On the other hand, Imbs (1999) has argued that countries with similar economic structures have better synchronised business cycles, in the light of the fact that the economic structure and its dynamics appear to play a more central role than trade in identifying whether or not a currency area has conditions for success. Following on from Imbs' (1999) work, several studies have shown that the similarities of economic structures can affect the correlation of business cycles across countries (Imbs 2004; Baxter - Kouparitsas 2005; Bower - Guillemineau 2006; Inklaar et al. 2008; Schiavo 2008; Siedschlag 2010). The majority of these studies focused on industrial and developing countries. Yet, the existing empirical evidence about the relationship between specialisation and business cycle synchronisation for euro area countries and also covering the crisis period is scarce.

1 De Grauwe - Mongelli (2005) offer a good review concerning the endogeneity of OCA. 
The study of specialisation patterns may be important for the future of the euro area because a high level of sectoral specialisation, following Krugman's hypothesis (1993), leads to increases in inter-industry trade and thus increases the vulnerability of individual countries to asymmetric shocks. The inverse is the case coming from a lower degree of specialisation and intra-industry trade. According to the new economic geography (e.g. Krugman 1991; Fujita et al. 1999), economic integration can (but might not) contribute to the increased specialisation of countries because the location of economic activity depends on the relative strength of two opposing forces: those of agglomeration and those of dispersion. Adopting a common currency by reducing trading costs and promoting the mobility of the factors of production influences the strength of agglomeration and dispersion forces. ${ }^{2}$

A number of studies have looked at patterns of specialisation of EMU member states. For example, Amiti (1999), Midelfart-Knarvik et al. (2000), Brülhart (2001), and Marelli (2007) show, based on data of output or employment for the manufacturing sector, that since the $1980 \mathrm{~s}$, the member states of the euro area have been slowly increasing their degree of specialisation. However, Brülhart - Elliott (1998), Brülhart (2001), and Böwer - Guillemineau (2006) conclude, based on trade data, that there is an increase in intra-industry trade, suggesting a downward trend of specialisation in the countries of the EMU.

A lot of empirical research has investigated the degree of business cycle synchronisation. The results have been mixed and seem sensitive to the time period, data set, investigation methods, and countries under observation. However, most of the evidence suggests that there have been both periods of greater and lesser synchronisation, and there is fairly substantial evidence that, since the 1990s, business cycle synchronisation has increased. ${ }^{3}$ Additionally, some studies suggest that there are important differences between certain groups of countries within the euro area. The four Southern European countries, Greece, Italy, Portugal, and Spain, are almost always included in a peripheral group considered to be more vulnerable to asymmetric shocks (e.g. Bayoumi - Eichengreen 1993; Lehwald 2013).

On the other hand, the current sovereign debt crisis has exposed weaknesses in the economies of the South. In particular, the size of public debt, the deficits and a lack of competitiveness have become evident. This has led to serious problems of adjustment, which have proven particularly very costly in terms of output

2 For a full survey of the predictions of new economic geography models on the effects of economic integration on specialisation patterns, see, for example, Ascani et al. (2012).

De Haan et al. (2008) provide a comprehensive survey of the empirical literature about business synchronisation in the euro area along with its underlying factors. 
and employment. The rapid increase in interest rate spreads that these economies had to face prevented access to international financial markets and forced first Greece, then Portugal to make a request for financial assistance and subsequently to adopt severe austerity measures. Spain and Italy seem to be less problematic cases than Greece and Portugal, but are also being obliged to pursue restrictive measures.

The importance of these problems and the lack of studies on the plight of Southern European economies were motives for choosing this topic of research for the present paper. The issue it analyses is of particular relevance because, if the euro area does not endogenously develop the conditions to be an optimal currency area, a new EMU institutional architecture will be needed if a break-up of the monetary union is to be avoided.

The contribution of this paper is twofold: (1) to analyse the sectoral export specialisation of Portugal, Greece, Italy, and Spain, and to compare this with export specialisation in the other euro area countries and their respective evolution over time; (2) to present evidence on the dynamics of synchronisation cycles in the euro area, both prior to the economic and financial crisis and following the period of crisis, and to examine whether the change in the pattern of specialisation of the export structure has influenced the synchronisation of business cycles.

The paper is organised as follows. The next section describes the data and the methods used in the empirical analysis. Section 3 analyses the degree of specialisation and similarity. Section 4 contains the results of business cycle synchronisation and econometric analysis. Section 5 concludes.

\section{DATA AND METHODS}

Our sample includes the first 12 countries that formed the euro area, namely Austria (AUT), Belgium (BEL), Finland (FIN), France (FRA), Germany (DEU), Spain (ESP), Greece (GRC), Ireland (IRL), Italy (ITA), Luxembourg (LUX), the Netherlands (NLD) and Portugal (PRT), and the aggregation of those countries (EA12). ${ }^{4}$

Our methodology consists of three stages. First, we analyse the evolution of specialisation patterns in the Portuguese, Greek, Spanish, and Italian economies. In order to do this, we study the export structures by product, calculating the weight of each exported product in total exports for each country.

4 Countries that have joined the EMU subsequently are not included due to the lack of data. These are Slovenia (2007), Cyprus and Malta (2008), Slovakia (2009), Estonia (2011), Latvia (2014), and Lithuania (2015). 
Next, in order to assess whether the process of economic and monetary integration in Europe has been accompanied by an increase in the similarity of export patterns, we construct and analyse four measures of the similarity of export structure between each country and the euro area aggregate, paying particularly close attention to the Southern European countries. ${ }^{5}$

The first indicator (SPEC1), proposed by Krugman (1991), is constructed as one minus the sum of the absolute differences of exports shares between country $i$ and the EA12:

$$
S P E C 1_{i, E A, t}=1-\sum_{n=1}^{N}\left|\frac{X_{i, n, t}}{X_{i, t}}-\frac{X_{E A, n, t}}{X_{E A, t}}\right|,
$$

where $X_{i, n, t}$ is the exports of product $n$ from country $i$, at time $t, X_{E A, n, t}$ is the exports of product $n$ from EA12, at time $t, X_{i, t}$ is the total exports of country $i, X_{E A, t}$ is the total exports of EA12 in year $t$, and $N$ corresponds to the total number of products.

Following Imbs (1999), we also use the index of conformity (SPEC2), defined analogously to the conventional correlation coefficient, but without consideration of the statistical mean:

$$
\operatorname{SPEC} 2_{i, E A, t}=\frac{\sum_{n=1}^{N} \frac{X_{i, n, t}}{X_{i, t}} \cdot \frac{X_{E A, n, t}}{X_{E A, t}}}{\sqrt{\left[\left(\sum_{n=1}^{N}\left(\frac{X_{i, n, t}}{X_{i, t}}\right)^{2}\right) \cdot\left(\sum_{n=1}^{N}\left(\frac{X_{E A, n, t}}{X_{E A, t}}\right)^{2}\right]\right.}} .
$$

The third indicator (SPEC3) is the similarity index developed by Finger Kreinin (1979). It is constructed as the sum of the minima of the sectoral shares of country $i$ and the EA12. ${ }^{6}$

$$
S P E C 3_{i, E A, t}=\sum_{n=1}^{N} \min \left(\frac{X_{i, n, t}}{X_{i, t}}, \frac{X_{E A, n, t}}{X_{E A, t}}\right)
$$

5 The advantages and disadvantages of such indicators can be found, for example, in Aiginger et al. (1999), Midekfart-Knarvik et al. (2000), Belke - Heine (2006), and Palan (2010).

6 The index goes from 0 to 1 as similarity increases. This index of export similarity has also been used, for example by Kaitila (2013). 
Finally, a fourth indicator (SPEC4) is similar to the Theil index. The index is determined by the following formula:

$$
\operatorname{SPEC4}_{i, E A, t}=1-\sum_{n=1}^{N}\left(\frac{X_{i, n, t}}{X_{i, t}} \cdot \ln \frac{\frac{X_{i, n, t}}{X_{i, t}}}{\frac{X_{E A, n, t}}{X_{E A, t}}}\right) .
$$

The higher the value of these indicators, the greater the similarity in export structure of a given country with the export structure of the euro area as a whole. Low values, on the other hand, stand for very different specialisation patterns. Furthermore, the greater the degree of the similarity of export structure, the lower the probability of asymmetric shocks occurring.

In order to calculate the indices, we used annual exports figures, at current prices (in USD terms) at the two-digit level of disaggregation of Standard International Trade Classification (SITC), Revision 3 of the United Nations (UN) with 67 product categories. ${ }^{7}$ The statistics were taken from the UN Comtrade database, available through World Integrated Trade Solutions (WITS). ${ }^{8}$ The data are annual and span the period from 1988 to 2012 .

To analyse the changes in specialisation patterns over time, we consider four sub-periods, marking important moments in the history of European economic and monetary integration. The first sub-period, which runs from 1981 to 1989, was marked by great stability in the functioning of the European Monetary System, and includes the implementation of the Single European Act. The second sub-period extends from 1990 to 1998, covering the implementation of several proposals made in the Delors Report and the possible effects of the Maastricht Treaty. The third sub-period begins in 1999 with the inception of EMU and follows through to 2007, when the onset of the financial crisis occurred. The last sub-period, from 2008 to 2012, corresponds to the economic and sovereign debt crisis in the euro area.

In the second stage, we analyse the output synchronisation in the euro area, emphasising the comparison between the four Southern European countries and the other euro area members. We use seasonally adjusted figures of quarterly real GDP, over the period 1981:1-2012:4. ${ }^{9}$

7 A list of products can be found in http://unstats.un.org/unsd/cr/registry/regcst.asp? $\mathrm{Cl}=14$.

8 Available from http://wits.worldbank.org/wits.

9 The quarterly GDP data are taken from the OECD National Accounts (see full details in Table Al of the Appendix). 
We begin by calculating the cyclical component of real GDP. To obtain the cyclical component, various non-parametric filtering methods can be used. However, empirical results might depend on the specific filter adopted (Canova 1998). In order to make our results robust, we apply the Band-Pass (BP) filter (Baxter King 1999) and the Hodrick-Prescott (HP) filter (Hodrick - Prescott 1997). ${ }^{10}$

Next, we calculate the Spearman correlation of cyclical component between every country's GDP and the euro area aggregate GDP. To examine the evolution of the degree of BCS along the sample period, we compute the correlation coefficients for the four sub-periods defined above.

Finally, the third stage concerns the econometric analysis, with the examination of the empirical relationship between export specialisation and output synchronisation among euro area countries. In order to estimate the effect of the degree of export similarity on output correlations, we ran the following panel regression equation:

$$
B C S_{i, E A, \tau}=\alpha_{0}+\alpha_{1} S P E C_{i, E A, \tau}+\varepsilon_{i, E A, \tau},
$$

where $B C S_{i, E A, \tau}$ denotes the GDP correlation coefficient between the cyclical component in country $i$ and the cyclical component in EA12 over time period $\tau$. We compute the business cycle using two filtering methods (BP filter and HP filter, designated $B C S 1$ and $B C S 2$, respectively). $S P E C_{i, E A, \tau}$ denotes the average of export specialisation indicators between country $i$ and the euro area at period $\tau$, using the four measures mentioned above. Lastly, $\varepsilon_{i, E A, \tau}$ expresses the disturbances in cyclical correlations beyond the influences of export specialisation. Our main interest lies in the sign of the coefficient $\alpha_{1}$. Most empirical evidence seems to be consistent with the possibility that similarity in export structure leads to a greater synchronisation of member country's cycles, so we expect a positive coefficient for export specialisation.

A problem with this equation is that export specialisation itself may be endogenous, i.e. economic and monetary integration may lead to the convergence of export structures of the euro zone countries. Following the literature, we apply a panel data with instrumental variable (IV) estimation. Instruments serve to separate the exogenous from the endogenous components in export specialisation indices.

10 Among the filters used, the BP filter is preferable from a theoretical point of view (Stock - Watson 1998). For this reason, and because we have obtained similar results, for the sake of brevity, we only present the BP filtered correlations in the study of business cycle synchronisation. 
Several authors (e.g. Imbs - Wacziarg 2003; Parteka - Tamberi 2013) conclude that the increase in income per capita is accompanied by a tendency towards a decrease in specialisation in manufacturing exports. Therefore, the instrument chosen is the log of the maxima of the ratio of income per capita between country $i$ and EA12 expressed as:

$$
\ln \left[\max \left(\frac{G D P p c_{i, \tau}}{G D P p c_{E A, \tau}}, \frac{G D P p c_{E A, \tau}}{G D P p c_{i, \tau}}\right)\right] .
$$

\section{SPECIALISATION PATTERNS}

This section examines changes in exports patterns in euro area countries over the last twenty-five years. First, we examine the export structure of Southern European countries (SE4), using the shares of each product in total exports. The analysis is then developed using different specialisation indices, in order to quantify the degree of similarity in export structure between each country and the euro area aggregate.

\subsection{Export structures of Southern European countries}

Figure 1 shows the ranking of the 10 most exported products in 2012 by Spain, Greece, Italy, and Portugal, comparing the weight of these products in three snapshots from 1988, 1999, and 2007.

As can be seen in Figure 1, in general, the four countries demonstrate different patterns of evolution in their exports.

The pattern of specialisation of Portuguese exports has changed significantly over the last 25 years. The most remarkable aspect is the continuous decrease throughout the period of the weight in the categories: "Articles of apparel and clothing accessories", "Textile products", and "Footwear".

In 1988, Portuguese exports were concentrated in "Textiles-clothing-footwear" accounting for $39 \%$ of total exports. However, by 2012, this figure dropped to $13 \%$. By comparison, "Road vehicles" and "Petroleum products", which in 1988 had represented $8 \%$ of total Portuguese exports, had grown significantly to $19 \%$ by 2012 .

Similarly to Portugal, Greece had a sharp reduction in the export share of "Articles of apparel and clothing accessories" throughout the period under analysis, from $23.9 \%$ in 1988 to $4.4 \%$ in 2012 . In contrast, "Non-ferrous metals" and "Medicinal and pharmaceutical products", which had accounted for $6.8 \%$ 
of total Greek exports in 1988, increased significantly to $14.4 \%$ of total exports in 2012. In the same period, the share of "Vegetables and fruit" did not change much, with the relative position reflecting the evolution of the weight of other products: in 1988, "Articles of apparel and clothing accessories" was first in the ranking and "Vegetables and fruit" was second, while in 2012, "Vegetables and

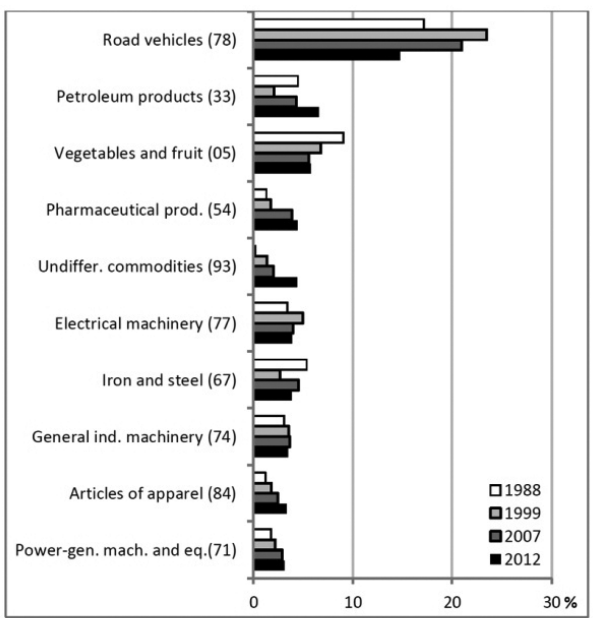

Spain

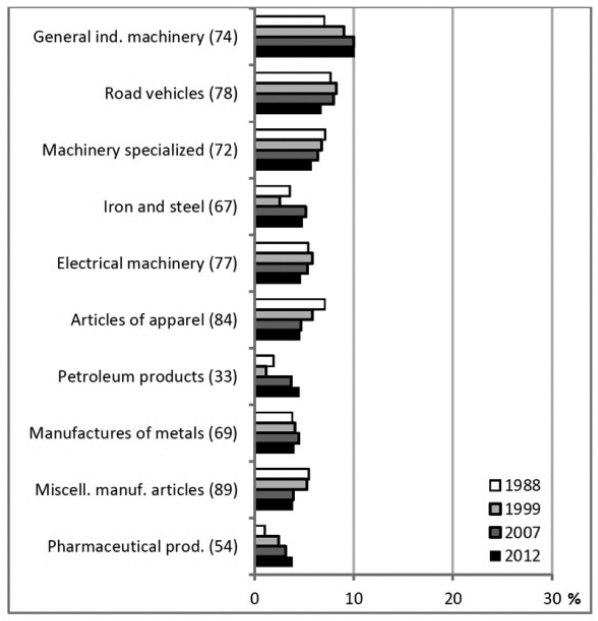

Italy

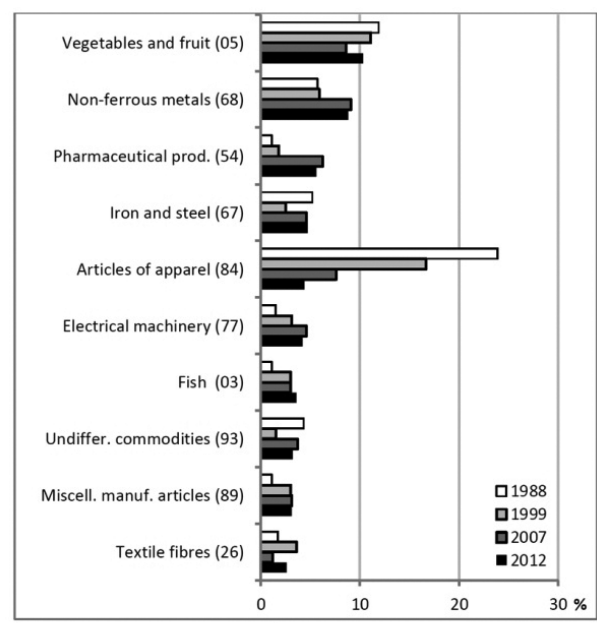

Greece

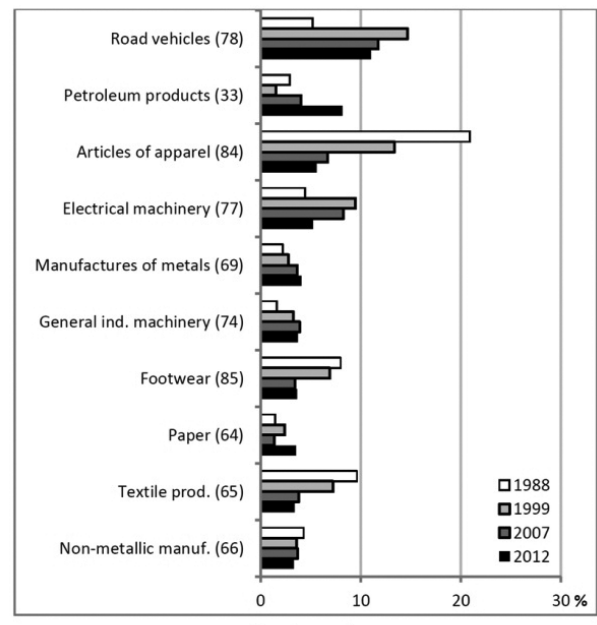

Portugal

Figure 1. Ranking of the 10 products most exported by Spain, Greece, Italy, and Portugal in 1988, 1999, 2007, and 2012, ordered by 2012

Source: UN Comtrade database, own calculations.

Note: Two-digit level of SITC Rev. 3. 
fruit" was the main export product and "Articles of apparel and clothing accessories" came fifth. ${ }^{11}$

The specialisation patterns of Spanish and Italian exports has not changed as much as those of Greece and Portugal. However, it should be noted that Spain and Italy were much less specialised economies and the weight of their ten most exported products remained relatively stable over time. Spanish exports registered an increase in the weight of "Medicinal and pharmaceutical products", from $1.3 \%$ in 1988 to $4.4 \%$ in 2012. At the same time, there was a decrease of the export share of "Vegetables and fruit", from $9 \%$ in 1988 to 5.8\% in 2012. In Italy, the sharpest rise was seen in exports of "General industrial machinery and equipment", from $7 \%$ in 1988 to $10.1 \%$ in 2012, and in exports of "Medicinal and pharmaceutical products", from $1 \%$ in 1988 to $3.1 \%$ in 2012, while the share of exports of "Articles of apparel and clothing accessories" decreased from $7.1 \%$ to $4.6 \%$ of total Italian exports.

\subsection{Similarity of export structure in euro area}

To analyse the similarity, we compared each of the country's exports with the aggregate EA12 exports. Figures A1, A2, A3, and A4 in Appendix show the evolution of the similarity of export structure in relation to the EA12, for the alternative specialisation measures defined above, in our sample countries from 1988 to 2012. During the period analysed, the indices of specialisation indicate a certain degree of stability in the similarity of export structure of each country in relation to that of the euro area aggregate, although this trend seems to become more pronounced in the Southern countries, especially in those where the initial export structure was more specialised (Greece and Portugal).

Table 1 provides the four indices for the four sub-periods defined provisionally. The analysis of Table 1 indicates the following conclusions:

The euro zone demonstrates a wide range of behaviours regarding the degree of specialisation of its member states.

- In the last sub-period, Germany has an export structure most similar to the aggregate of euro countries, followed by France, Spain, Austria, Belgium, Italy, Netherlands, and Portugal. On the other hand, the country furthest away from the euro area aggregate, showing the most specialised export structure, was Ireland, followed by Greece, Luxembourg, and Finland.

11 In line with the Greek Annual Report 2012 (Bank of Greece 2013, p. 117) and due to recent changes in the share of "Petroleum products and related materials (33)" in total Greek exports, and its relative insignificance in value added terms, we have excluded it from the analysis. 
- Regarding changes over time, the similarity of the export structure of each of the countries of Southern Europe with that of the euro area as a whole has increased over the four sub-periods. It is worth noting that Portugal and Greece still exhibit a degree of similarity of the export structure,

Table 1. Similarity of export structure vis-à-vis the EA12, four sub-periods

\begin{tabular}{|c|c|c|c|c|c|c|c|c|}
\hline \multirow{2}{*}{ Country } & $\begin{array}{c}1988- \\
89 \\
\end{array}$ & $\begin{array}{c}1990- \\
98 \\
\end{array}$ & $\begin{array}{c}1999- \\
2007 \\
\end{array}$ & $\begin{array}{c}2008- \\
12 \\
\end{array}$ & $\begin{array}{c}1988- \\
89 \\
\end{array}$ & $\begin{array}{c}1990- \\
98 \\
\end{array}$ & $\begin{array}{c}1999- \\
2007 \\
\end{array}$ & $\begin{array}{c}2008- \\
12 \\
\end{array}$ \\
\hline & \multicolumn{4}{|c|}{ SPEC1 } & \multicolumn{4}{|c|}{ SPEC2 } \\
\hline ESP & 0.52 & 0.51 & 0.54 & 0.57 & 0.89 & 0.88 & 0.89 & 0.90 \\
\hline GRC & -0.21 & -0.11 & 0.11 & 0.22 & 0.35 & 0.37 & 0.49 & 0.61 \\
\hline ITA & 0.47 & 0.47 & 0.45 & 0.49 & 0.86 & 0.86 & 0.84 & 0.86 \\
\hline PRT & 0.03 & 0.13 & 0.33 & 0.38 & 0.49 & 0.61 & 0.80 & 0.84 \\
\hline Average SE4 & 0.20 & 0.25 & 0.36 & 0.42 & 0.65 & 0.68 & 0.75 & 0.80 \\
\hline AUT & 0.44 & 0.47 & 0.53 & 0.55 & 0.81 & 0.87 & 0.91 & 0.91 \\
\hline BEL & 0.53 & 0.55 & 0.56 & 0.53 & 0.88 & 0.88 & 0.89 & 0.87 \\
\hline DEU & 0.70 & 0.71 & 0.72 & 0.71 & 0.97 & 0.96 & 0.97 & 0.96 \\
\hline FIN & 0.12 & 0.18 & 0.12 & 0.23 & 0.47 & 0.51 & 0.53 & 0.64 \\
\hline FRA & 0.75 & 0.75 & 0.73 & 0.67 & 0.97 & 0.96 & 0.95 & 0.92 \\
\hline IRL & 0.06 & 0.01 & -0.06 & -0.11 & 0.47 & 0.49 & 0.51 & 0.51 \\
\hline LUX & - & - & 0.17 & 0.16 & - & - & 0.57 & 0.57 \\
\hline NLD & 0.43 & 0.45 & 0.40 & 0.40 & 0.76 & 0.77 & 0.72 & 0.75 \\
\hline \multirow[t]{2}{*}{ Av. others } & 0.43 & 0.45 & 0.40 & 0.40 & 0.76 & 0.78 & 0.76 & 0.76 \\
\hline & \multicolumn{4}{|c|}{ SPEC3 } & \multicolumn{4}{|c|}{ SPEC4 } \\
\hline ESP & 0.75 & 0.74 & 0.77 & 0.78 & 0.76 & 0.78 & 0.82 & 0.85 \\
\hline GRC & 0.38 & 0.44 & 0.55 & 0.61 & -0.13 & -0.02 & 0.27 & 0.44 \\
\hline ITA & 0.73 & 0.73 & 0.73 & 0.75 & 0.75 & 0.75 & 0.76 & 0.79 \\
\hline PRT & 0.50 & 0.55 & 0.66 & 0.69 & 0.09 & 0.24 & 0.56 & 0.67 \\
\hline Average SE4 & 0.59 & 0.62 & 0.68 & 0.71 & 0.38 & 0.44 & 0.60 & 0.69 \\
\hline$\overline{A U T}$ & 0.71 & 0.72 & 0.76 & 0.77 & 0.76 & 0.79 & 0.85 & 0.84 \\
\hline BEL & 0.76 & 0.76 & 0.78 & 0.77 & 0.84 & 0.86 & 0.84 & 0.83 \\
\hline DEU & 0.84 & 0.84 & 0.86 & 0.85 & 0.93 & 0.95 & 0.94 & 0.94 \\
\hline FIN & 0.55 & 0.58 & 0.56 & 0.62 & 0.19 & 0.29 & 0.31 & 0.47 \\
\hline FRA & 0.87 & 0.86 & 0.86 & 0.83 & 0.92 & 0.92 & 0.92 & 0.89 \\
\hline IRL & 0.52 & 0.49 & 0.47 & 0.44 & 0.29 & 0.30 & 0.19 & 0.14 \\
\hline LUX & - & - & 0.58 & 0.58 & - & - & 0.42 & 0.38 \\
\hline NLD & 0.70 & 0.71 & 0.70 & 0.70 & 0.78 & 0.77 & 0.72 & 0.74 \\
\hline Av. others & 0.71 & 0.71 & 0.70 & 0.69 & 0.67 & 0.69 & 0.65 & 0.65 \\
\hline
\end{tabular}

Source: UN Comtrade database and own calculations.

Note: The data on exports for Luxembourg are only available from 1999. 
which is much lower than the average of the SE4 countries despite having increased the degree of similarity with the EA12 export structure, and the average for the group of the rest of the EMU economies. However, this difference is much higher in the first sub-period than in the last subperiod. It can also be noted that Greece shows a structure of exports with less resemblance than Portugal. ${ }^{12}$

- With regard to the group of the 8 remaining countries, most maintained the degree of similarity of export structure relative to EA12. Exceptions to this were Austria, Germany, and Finland, which have increasingly come to resemble the euro area. Conversely, Ireland recorded a decrease in the level of similarity with the euro area.

- When comparing the specialisation indices of the third and fourth subperiod, it seems clear that some countries have slightly decreased the degree of similarity in relation to the EA12, perhaps due to the effect of the economic and financial crisis. This trend is present in France, Ireland, and Luxembourg.

Taken as a whole, the results suggest that the deepening of European integration has influenced the progress of the pattern of specialisation of the economies of the euro area, making them increasingly similar to the aggregate of the EA12. Even so, there are countries that have become more specialised, as is the case of Ireland. Additionally, the global economic and financial crisis and the subsequent European debt crisis appear not to have affected much the patterns of convergence of the export structure of countries in the euro area. These findings are consistent with other literature relating to this matter (e.g. Kaitila 2013).

\section{EXPORT SPECIALISATION AND SYNCHRONISATION: ESTIMATION AND RESULTS}

The effect of similarity in export structures on the output synchronisation must be viewed with caution. Business cycle synchronisation depends not only on sectoral structures, but on many other variables, comprising policies and institutions. On the one hand, monetary policy is centralised and identical for all euro area countries, but transmission mechanisms may be different across countries. On the

12 For a recent discussion of the particular composition of Greek exports, see Alcidi - Gros (2015). 
other hand, fiscal policies are really different and have been used in diverse ways in recent years, which is due to the various fiscal conditions in different countries (debt/GDP ratio and debt crisis contagion, among others). ${ }^{13}$

\subsection{Synchronisation}

The results of correlation coefficients between each euro area country and the EA12 aggregate cycle for the four selected sub-samples are provided in Table 2.

Table 2. Business cycle synchronisation vis-à-vis the EA12, four sub-periods

\begin{tabular}{l|c|c|c|c|}
\hline & $1981: 1-1989: 4$ & $1990: 1-1998: 4$ & $1999: 1-2007: 4$ & $\mathbf{2 0 0 8 : 1 - 2 0 1 2 : 4}$ \\
\hline ESP & 0.22 & $0.91^{* * *}$ & $0.89^{* * *}$ & $0.90^{* * *}$ \\
GRC & $0.78^{* * *}$ & $0.51^{* * *}$ & 0.16 & 0.00 \\
ITA & $0.94^{* * *}$ & $0.82^{* * *}$ & $0.90^{* * *}$ & $0.96^{* * *}$ \\
PRT & 0.06 & $0.57^{* * *}$ & $0.79^{* * *}$ & $0.64^{* * *}$ \\
\hline Average SE4 & $\mathbf{0 . 5 0}$ & $\mathbf{0 . 7 0}$ & $\mathbf{0 . 6 9}$ & $\mathbf{0 . 6 3}$ \\
\hline AUT & -0.16 & $0.87^{* * *}$ & $0.90^{* * *}$ & $0.97^{* * *}$ \\
BEL & $0.79^{* * *}$ & $0.90^{* * *}$ & $0.83^{* * *}$ & $0.98^{* * *}$ \\
DEU & $0.62^{* * *}$ & $0.95^{* * *}$ & $0.96^{* * *}$ & $0.98^{* * *}$ \\
FIN & $0.41^{* *}$ & $0.33^{* *}$ & $0.86^{* * *}$ & $0.99^{* * *}$ \\
FRA & $0.40^{* *}$ & $0.92^{* * *}$ & $0.93^{* * *}$ & $0.99^{* * *}$ \\
IRL & - & - & $0.87^{* * *}$ & $0.90^{* * *}$ \\
LUX & - & - & $0.84^{* * *}$ & $0.94^{* * *}$ \\
NLD & $0.82^{* * *}$ & $0.82^{* * *}$ & $0.90^{* * *}$ & $0.92^{* * *}$ \\
\hline Av. others & $\mathbf{0 . 4 8}$ & $\mathbf{0 . 8 0}$ & $\mathbf{0 . 9 0}$ & $\mathbf{0 . 9 7}$ \\
\hline
\end{tabular}

Source: Author's calculations.

Note: ${ }^{*},{ }^{* *}$, and ${ }^{* * *}$ denote significance at the $10 \%, 5 \%$, and $1 \%$ levels, respectively.

The main aspect to be emphasised is that with the exception of Greece, all countries increased their synchronisation with respect to the euro area after the inception of the EMU. Comparing the two groups of countries, the business cycles of the Southern European countries are, on average, less synchronised with the euro area aggregate than the other countries in all sub-periods (except in the first sub-period which is similar). It is also demonstrable that the difference increased in the recent crisis period (2008-2012).

13 See, for example, Böwer - Guillemineau (2006) for an analysis of a variety of potential determinants of cycle synchronisation in the euro zone. 
However, there are great differences in the SE4 group. Prior to the launch of the euro, Italy experienced the highest level of synchronisation with the euro area cycle, followed by Greece and Spain; Portugal had a low level of synchronisation. In the third sub-period, with the exception of Greece for which the correlation decreased considerably, the synchronisation of Southern European countries with the euro area aggregate became higher and their patterns more similar. Even so, the eruption of the global financial crisis in August 2007 and its intensification in September 2008 meant that Greece and Portugal were affected by the crisis, and this is reflected in the decrease in synchronisation with the euro area cycle.

It should also be noted that while Italy and Spain exhibited similar behaviour to other European countries over the four sub-periods, Greece and Portugal behaved differently. Greece is a peculiar case: in the first sub-period it had a high correlation, then it experienced a decrease in the 1990s and a decoupling from the euro area cycle after the introduction of the euro. The other eight economies of our sample have a similar and strong association with the euro area cycle. In the last sub-period, the correlations are higher than 0.90. Only Ireland did not exceed that level, even though it did improve.

These findings are in line with a number of recent contributions. Quah (2014b), for instance, using fuzzy cluster analysis over 1993-2011, has detected that the degree of symmetry with EA12 has generally increased, despite the distances between each of the countries in that aspect having grown. ${ }^{14}$

\subsection{The effect of sectoral specialisation on synchronisation}

Table 3 reports the IV estimates of the effect of similarity in export structure on output synchronisation, using specialisation measures instrumented by GDP per capita. The estimates are presented in four columns, corresponding to the four different specialisations indices. For each index, two estimates are presented in rows, relating to the two filters.

These results indicate that the estimated coefficients are positive and statistically significant at the $1 \%$ level, suggesting that similarities in export specialisation patterns were associated with higher correlations of the country's business cycle with the euro area cycle in the period 1981-2012. Moreover, the regression results are robust with respect to the choice of export specialisation indices and to different measures of business cycle co-movement used in the regression model.

Our findings suggest that, for our sample, if business cycles arise principally due to sector-specific shocks, then the countries with export structures most simi-

14 See also Quah (2014a, 2014b). 
Table 3. IV estimates of the effects of export specialisation on synchronisation

\begin{tabular}{l|cccc}
\hline & SPEC1 & SPEC2 & SPEC3 & SPEC4 \\
\hline BCS1 & 0.769 & 1.484 & 1.897 & 0.6781 \\
& $(3.12)$ & $(2.89)$ & $(2.98)$ & $(3.07)$ \\
BCS2 & 0.688 & 1.328 & 1.698 & 0.699 \\
& $(3.07)$ & $(2.85)$ & $(2.94)$ & $(3.01)$ \\
\hline
\end{tabular}

Note: All coefficients are statistically significant at the $1 \%$ level. Numbers in parenthesis represent $t$-statistics. Intercepts not reported. Instrumental variable for export specialisation is the GDP per capita. Data for 10 euro area countries, from 1981 to 2012, split into four sub-periods. Sample size $=40$.

lar to the euro area export structure will tend to have, ceteris paribus, more correlated business cycles. This is in line with the results of Imbs (2004), Inklaar et al. (2008), Schiavo (2008), and Siedschlag (2010).

\section{CONCLUSIONS}

In this paper, we have analysed the evolution of synchronisation between $12 \mathrm{EU}$ member states' business cycles and the aggregate euro area from 1981 to 2012 and the effect of the degree of similarity of export structures on this process. One aim of the research was to assess to what extent the euro area has endogenously developed the conditions to be an optimal currency area during its first 15 years of existence. The analysis has placed particular emphasis on the Southern countries (Spain, Greece, Italy, and Portugal), which face a lot of challenges, such as trying to achieve sustainable public finances, improving competiveness in the context of a deep economic recession, and dealing with high unemployment.

A key element of the OCA theory is the synchronisation of business cycles across member states to guarantee that the common monetary policy is adequate for each country's individual requirements. Overall, we find that almost all euro zone countries have become more highly synchronised over the sample period and that in some way, this increase in synchronisation may be explained by the ever greater similarity of export structure between each member state and the euro area aggregate, particularly those that had the most dissimilar export structures at the beginning of the period.

The analysis of the four specialisation indices revealed that between 1988 and 2012, export specialisation in Southern European countries evolved differently. Greece and Portugal, the countries with the highest degree of specialisation in 1988, have modified their export structure, becoming increasingly similar to the euro area. Although Greece has an increasing similarity of export structure vis-àvis the euro area aggregate, it remains a more specialised economy than Portugal. 
It should be noted that both Spain and Italy's export patterns are close to that of the euro area as a whole. Italy remained relatively stable throughout the period. However, Spain has become less specialised.

The period of financial and sovereign debt crisis corresponded to an intensification in the synchronisation of cycles in almost all countries, except for Portugal and Greece. In general, export specialisation in the euro area countries did not change very much in this period.

Furthermore, the regression results provide evidence that similarity in export structures was positively and significantly associated with the correlation between the individual cycles of member states and the euro area cycle as a whole. This suggests that, given that there seems to be a trend towards the greater similarity of export structure, euro area countries can be better protected against sectorspecific adverse shocks and, consequently, may have more synchronised business cycles.

All in all, we cannot draw any strong conclusion about the effectiveness of the "one size fits all" European Central Bank policies. Nevertheless, the evidence for the first years of EMU and of a gradual decline in export specialisation seems to support the "endogeneity of OCA's criteria" hypothesis. The question is to what extent these tendencies can be maintained or changed over time.

Notwithstanding, it will be necessary, on the one hand, to implement policies to end the fiscal crisis and the current stagnation in the southern countries that are faced with austerity policies. On the other hand, it will be necessary to take further European governance reforms by carrying out measures aimed at transforming and strengthening the Stability and Growth Pact, reinforcing the Macroeconomic Imbalance Procedure to monitor competitiveness and external imbalances, and completing the banking union. These measures should be carried out in order, among others, to sustain "real convergence" and thereby ensure that, as far as possible, crises in the EMU do not have such harmful effects in the future.

\section{REFERENCES}

Aiginger K. - Boeheim, M. - Gugler, K. - Pfaffermayr, M. - Wolfmayr-Schnitzer, Y. (1999): Specialization and (Geographic) Concentration of European Manufacturing. Working Paper, EUCommission - Enterprise DG, Brussels.

Alcidi, C. - Gros, D. (2015): The Greek Economy is Unlikely to Benefit from Further Devaluation. CEPS Commentary, 3 July.

Amiti, M. (1999): Specialisation Patterns in Europe. Weltwirtschaftliches Archiv, 135(4): 573593.

Ascani, A. - Crescenzi, R. - Iammarino, S. (2012): New Economic Geography and Economic Integration: A Review. EU-Commission, Search Working Paper, WP 1/02.

Bank of Greece (2013): Annual Report 2012. 
Bank of Portugal (2010): Quarterly Series for the Portuguese Economy. Economic Bulletin, Summer.

Bayoumi, T. - Eichengreen, B. (1993): Shocking Aspects of European Monetary Unification. In: Torres, F. - Giavazzi, F. (eds): Adjustment and Growth in the European Monetary Union. Cambridge University Press, 193-229.

Baxter, M. - King, R. (1999): Measuring Business Cycles: Approximate Band-Pass Filters for Economic Time Series. Review of Economics and Statistics, 81(4): 575-593.

Baxter, M. - Kouparitsas, M. (2005): Determinants of Business Cycle Co-Movement: A Robust Analysis. Journal of Monetary Economics, 52(1): 113-57.

Belke, A. - Heine, J. (2006): Specialisation Patterns and the Synchronicity of Regional Employment Cycles in Europe. International Economic and Economic Policy, 3(2): 91-104.

Böwer, U. - Guillemineau, C. (2006): Determinants of Business Cycle Synchronisation across Euro Area Countries. ECB Working Paper, No. 587.

Brülhart, M. (2001): Growing Alike or Growing Apart? Industrial Specialisation of EU Countries. In: Wyplosz, C. (ed.): The Impact of EMU on Europe and the Developing Countries. Oxford: Oxford University Press.

Brülhart, M. - Elliott, R. (1998): Adjustment to the European Single Market: Inferences from IntraIndustry Trade Patterns. Journal of Economic Studies, 135(4): 1-21.

Buti M. - Sapir, A. (eds) (1998): Economic Policy in EMU. Oxford: Oxford University Press.

Canova, F. (1998): Detrending and Business Cycle Facts. Journal of Monetary Economics, 41(3): 533-40.

Chen, R. - Milesi-Ferreti, G. - Tressel, T. (2013): External Imbalances in the Eurozone. Economic Policy, 28(73):101-142.

De Grauwe, P. - Mongelli, F. (2005): Endogeneities of Optimum Currency Areas: What Brings Countries Sharing a Single Currency Together? Working Paper, No 468, European Central Bank, Frankfurt.

De Haan, J. - Inklaar, R. - Jong-A-Pin, R. (2008): Will Business Cycles in the Euro Area Converge? A Critical Survey of Empirical Research. Journal of Economic Surveys, 22(2): 234-273.

Finger, J. - Kreinin, M. (1979): A Measure of 'Export Similarity' and Its Possible Uses. Economic Journal, 89(356): 905-912.

Fujita, M. - Krugman, P. - Venables, V. (1999): The Spatial Economy: Cities, Regions, and International Trade. Cambridge: MIT Press.

Gunther, S. - Wollmershäuser, T. (2013): Fiscal Divergence and Current Account Imbalances in Europe. CESifo Working Paper, No. 4108, February.

Hodrick, R. - Prescott, E. (1997): Post-war U.S. Business Cycles: An Empirical Investigation. Journal of Money Credit and Banking, 29(1): 1-16.

Imbs, J. (1999): Co-Fluctuations. CEPR Discussion Paper, No. 2267.

Imbs, J. (2004): Trade, Finance, Specialization and Synchronization. Review of Economics and Statistics, 868(3): 723-734.

Imbs, J. - Wacziarg, R. (2003): Stages of Diversification. American Economic Review, 93(1): 6386.

Inklaar, R. - Jong-A-Pin, R. - De Haan, J. (2008): Trade and Business Cycle Synchronization in OECD Countries - A Re-Examination. European Economic Review, 52(4): 646-666.

Kaitila, V. (2013): Specialisation and/or Convergence - Structure of European Exports and Production. Research Institute of Finnish Economy (ETLA) Working Papers, No. 14.

Kenen, P. (1969): The Theory of Optimum Currency Areas: An Eclectic View. In: Mundell, R. Swoboda, K. (eds): Monetary Problems of the International Economy. Chicago: University of Chicago Press, pp. 41-60. 
Kim, J-H - Kim, J. (2014): Intra and Offshore Trade in the Euro Zone and Trade Imbalances. Applied Economics Letters, 21(15): 1060-1064.

Krugman, P. (1991): Increasing Returns and Economic Geography. Journal of Political Economy, 99(3): 483-99.

Krugman, P. (1993): Lessons from Massachusetts for EMU. In: Torres, F. - Giavazzi, F. (eds): Adjustment and Growth in the European Union. Cambridge: Cambridge University Press, pp. 241-260.

Lehwald, S. (2013): Has the Euro Changed Business Cycle Synchronization? Evidence from the Core and the Periphery. Empirica, 40(4): 655-684.

Marelli, E. (2007): Specialisation and Convergence of European Regions. The European Journal of Comparative Economics Studies, 4(2): 149-178.

McKinnon, R. (1963): Optimum Currency Areas. American Economic Review, 53(4): 717-725.

Midelfart-Knarvik, K. - Overman, H. - Reading, S. - Venables, A. (2000): The Location of European Industry. European Economy - Economic Papers, European Commission, No. 142.

Mongelli, F. (2005): What is European Economic and Monetary Union Telling Us about the Properties of Optimum Currency Areas? Journal of Common Market Studies, 43(3): 607-635.

Mundell, R. (1961): A Theory of Optimum Currency Areas. American Economic Review, 51(4): $657-665$.

Quah, C. H. (2014a): Clustering Eurozone Cycles. Quality \& Quantity, 48: 3447-3462.

Quah, C. H. (2014b): Revisiting Business Cycles in the Eurozone: A Fuzzy Clustering and Discriminant Approach. Acta Oeconomica, 64(2): 161-180.

Quah, C. H. (2014c): Un diagnóstico de Grecia. Investigación económica, 73(287): 3-35.

Palan, N. (2010): Measurement of Specialization -The Choice of Indices. Research Centre International Economics, Vienna (FIW) Working Paper, No. 62.

Parteka, A. - M. Tamberi, M. (2013): What Determines Export Diversification in the Development Process? Empirical Assessment. The World Economy, 36(6): 807-826.

Schiavo, S. (2008): Financial Integration, GDP Correlation and the Endogeneity of Optimum Currency Areas. Economica, 75(297): 168-189.

Siedschlag, I. (2010): Patterns and Determinants of Business Cycle Synchronization in the Enlarged European Economic and Monetary Union. Eastern Journal of European Studies, 1(1): 21-44.

Stock, J. - Watson, M. (1998): Business Cycle Fluctuations in U. S. Macroeconomics Time Series. NBER Working Paper, No. 6528. 


\section{APPENDIX}

Table A1. Available data for GDP, sample periods and sources

\begin{tabular}{l|ccl}
\hline Country & Code & Sample Period & Source \\
\hline Austria & AUT & $1981: 1-2012: 4$ & OECD $(1968: 1-2013: 4)$ \\
Belgium & BEL & $1981: 1-2012: 4$ & OECD $(1980: 1-2013: 4)$ \\
Finland & FIN & $1981: 1-2012: 4$ & OECD $(1970: 1-2013: 4)$ \\
France & FRA & $1981: 1-2012: 4$ & OECD $(1968: 1-2013: 4)$ \\
Germany & DEU & $1981: 1-2012: 4$ & OECD $(1970: 1-2013: 4)$ \\
Greece & GRC & $1981: 1-2012: 4$ & OECD $(1970: 1-2012: 4)$ \\
Ireland & IRL & $1997: 1-2012: 4$ & OECD $(1997: 1-2013: 4)$ \\
Italy & ITA & $1981: 1-2012: 4$ & OECD $(1968: 1-2012: 4)$ \\
Luxembourg & LUX & $1995: 1-2012: 4$ & OECD $(1995: 1-2013: 3)$ \\
Netherlands & NLD & $1981: 1-2012: 4$ & OECD $(1977: 1-2013: 4)$ \\
Portugal & PRT & $1981: 1-2012: 4$ & OECD and BdP $(1978: 1-2013: 4)$ \\
Spain & ESP & $1981: 1-2012: 4$ & OECD $(1970: 1-2013: 4)$ \\
euro area & EA12 & $1981: 1-2012: 4$ & OECD (1970:1-2013:4) \\
\hline
\end{tabular}

Note: The main source is the OECD National Account's database. In the case of Portugal, the data published by OECD in the period 1995:1-2013:4 have been completed retrospectively with data from the Bank of Portugal (BdP), “Quarterly Series for the Portuguese Economy” (Economic Bulletin, Summer of 2010).

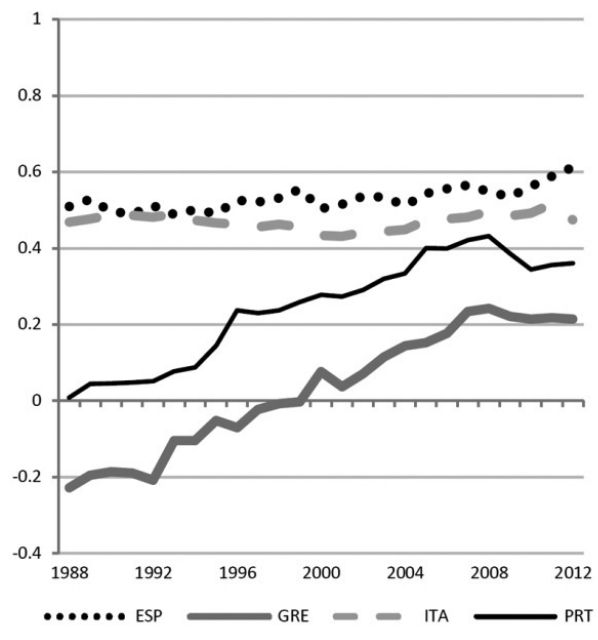

Southern euro area countries

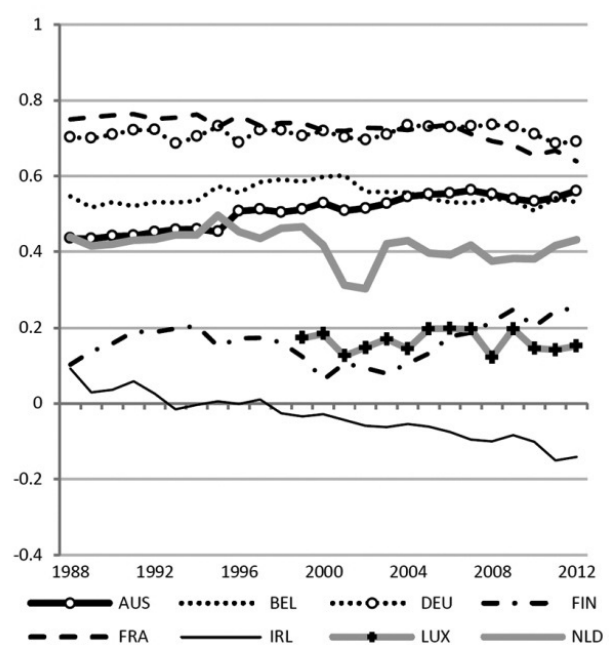

Other euro area countries

Figure A1. Similarity of export structure vis-à-vis the EA12, Krugman index (SPEC1), 1988-2012 Source: UN Comtrade database, own calculations. 


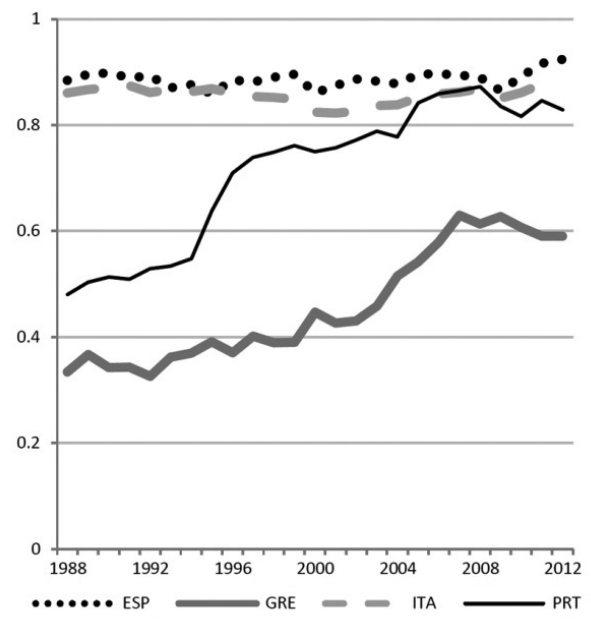

Southern euro area countries

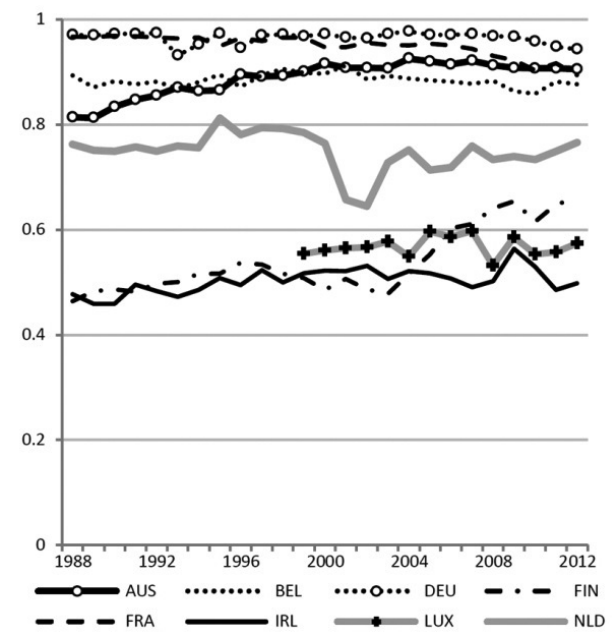

Other euro area countries

Figure A2. Similarity of export structure vis-à-vis the EA12, index of conformity (SPEC2),

1988-2012

Source: UN Comtrade database, own calculations.

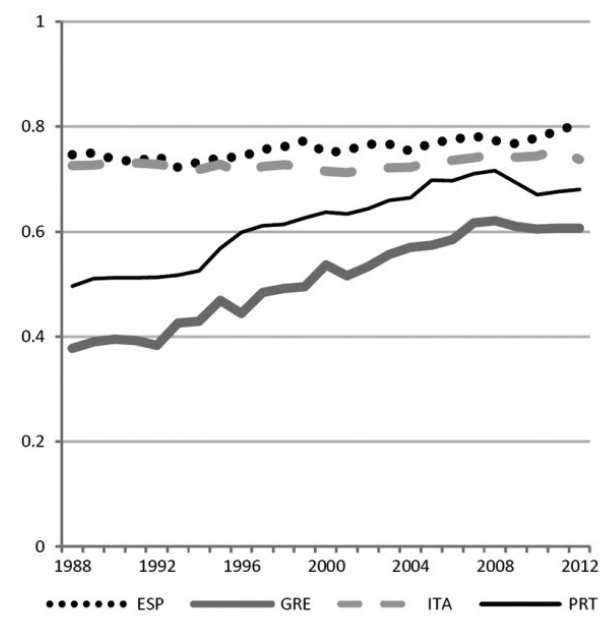

Southern euro area countries

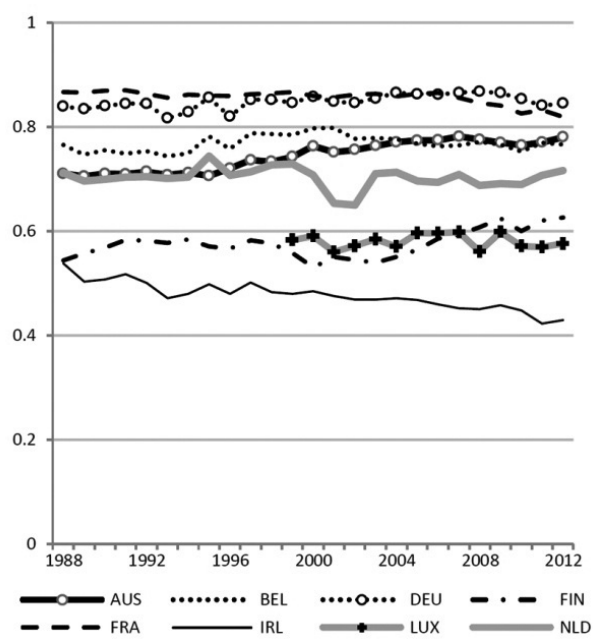

Other euro area countries

Figure A3. Similarity of export structure vis-à-vis the EA12, Finger-Kreinin index (SPEC3), 1988-2012

Source: UN Comtrade database, own calculations. 


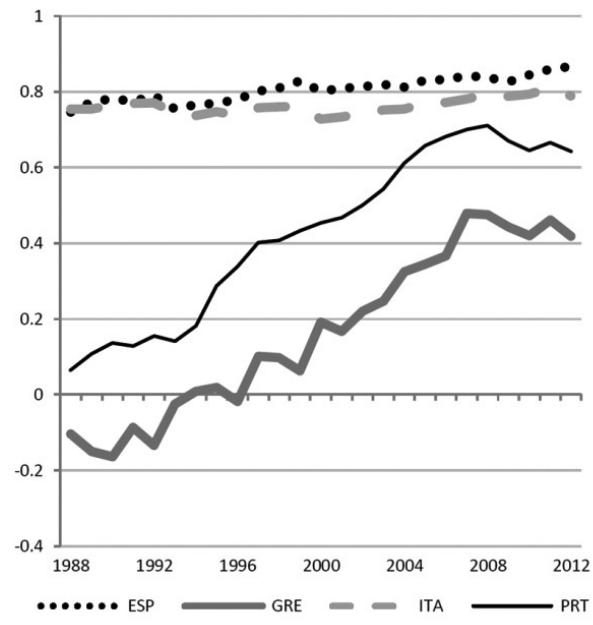

Southern euro area countries

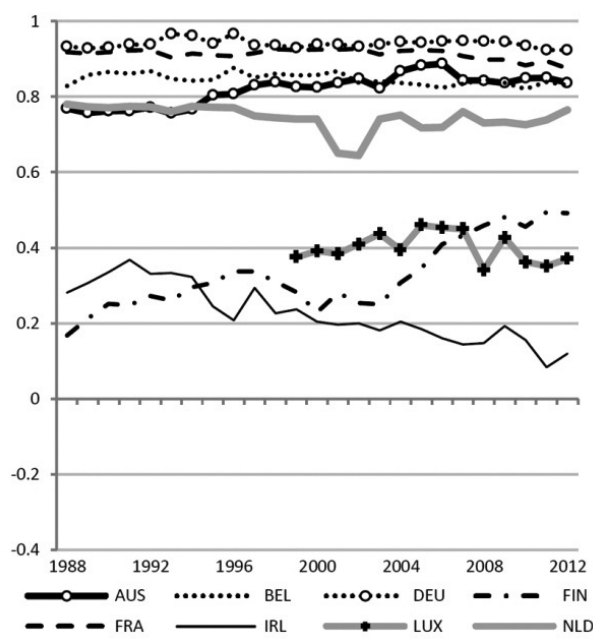

Other euro area countries

Figure A4. Similarity of export structure vis-à-vis the EA12, Theil index (SPEC4), 1988-2012 Source: UN Comtrade database, own calculations. 